\title{
KARISMA K.H. MUHAMMAD ZAINI ABDUL GHANI DAN PERAN SOSIALNYA (1942-2005)
}

\author{
Mirhan AM \\ Jurusan Perbandingan Agama Fakultas Ushuluddin dan Humaniora \\ IAIN Antasari Banjarmasin \\ Jl. A. Yani Km 4,5 Banjarmasin \\ Diterima tanggal 20 Agustus 2012/Disetujui tanggal 20 Oktober 2012
}

\begin{abstract}
In this exposure, the author proposed about KH Mubammad Zaini Abdul Ghani, the study on charisma and social role and Kharisma of KH Mubammad Zaini Abd. Ghani also supported by the ability to master the classical Islamic sciences. He was able to explain the concepts and to construct elaborate religious in simple language. Therefore, when listening to the description of his talk was easy to understand, understood and grown the love (awe) to him. Feelings of love and admiration were also growing in the hearts of thousands of his disciples. Therefore, a lot of people who liked to tell his karamah - Karamah, although teachers themselves said, Karamah not very important for one's piety, but the consistency in doing good, more better than a thousand Karamah. Once passed away into Rahmatullah, the tomb of K.H. Mubammad Zaini Abd. Ghani always visited by the public until now. Hundreds of people come every day from various parts of this city. This shows that his charisma is not lost when the person dies.
\end{abstract}

Kata kunci: Karisma, keturunan, Martapura, ilmu keislaman klasik

\section{Pendahuluan}

Di Kalimantan Selatan tepatnya di Martapura telah lahir seorang ulama yang menjadi panutan umat. Dia dikenal sebagai ulama besar. Namanya adalah K.H. Muhammad Zaini Abdul Ghani, atau lebih populer disebut Abah Guru Ijai atau Guru Sekumpul.

K.H. Muhammad Zaini Abdul Ghani merupakan salah satu Tuan Guru yang merupakan keturunan dari Syekh Muhammad Arsyad alBanjari. Dia seorang ulama besar pembimbing umat, yang mempunyai 
karisma ${ }^{1}$ yang sangat dicintai oleh masyarakat. Kecintaan masyarakat terhadap ulama kharismatik ini sangat besar sekali. Ini dapat dilihat dari beberapa fenomena antara lain:

a. Foto dan gambar K.H. Muhammad Zaini Abdul Ghani atau dikenal dengan sebutan $A b a b$ Guru $^{2}$ dari ukuran kecil sampai ukuran besar dipajang/dijual di seluruh toko dalam komplek Sekumpul ${ }^{3}$ dan di luar komplek Sekumpul yaitu di toko-toko, di kios-kios, di pasar-pasar di Kalimantan Selatan, bahkan mayoritas di rumah-rumah, warung-warung, restoran di Banjarmasin memajang foto-fotonya dengan bermacam ukuran.

b. Kaset-kaset ceramah/dakwah selalu dicari oleh masyarakat bahkan mereka rela mengeluarkan jutaan rupiah untuk membeli kaset-kaset ceramah yang sempat terekam oleh M. Yusuf Kabul. ${ }^{4}$ Kaset-kaset tersebut berisi bermacam-macam petuah agama yang menyangkut

\footnotetext{
${ }^{1}$ Menurut Weber, istilah karisma digunakan terhadap sifat tertentu pada seseorang yang karenanya orang tersebut dibedakan dengan orang biasa dan dipandang mendapat kekuatan adikodrati, adimanusiawi atau paling tidak luar biasa kekuatannya sedemikian rupa sehingga tidak terjangkau oleh orang biasa tetapi dianggap sebagai berasal dari Tuhan atau sebagai teladan dan atas dasar itu individu tersebut diperlakukan sebagai seorang pemimpin. Lihat Max Weber, The Theory of Social and Economic Organization, trans. A.M. Henderson and Talcott Parsons (Newyork: The Falcon Wings Press, 1947), h. 359. Lihat Bryan Wilson, The Noble Savages The Primitive Origins of Charisma and its Contemporery Survival (Berkeley: University of California Press, 1975), h. 4. Lihat juga David L. Sills, International Encyclopedia of the Social Sciences, (New York: the Macmillan Company \& the Free Press, t. th.), vol. 1, h. 386 - 387. Lihat juga Joachim Wach, Sociology of Religion, (Chicago: The University of Chicago Press, 1962), h. 337 - 341 dan lihat Thomas F. O. Dea, Sosiologi Agama suatu Pengenalan Awal, Tim penerjemah Yasogama (Jakarta: Rajawali Press, 1990), h. 44.

${ }^{2} \mathrm{Abah}$ guru adalah sebutan atau panggilan terhadap K.H. Muhammad Zaini Abdul Ghani oleh masyarakat Kalimantan.

${ }^{3}$ Sekumpul adalah komplek/wilayah pemukiman rumah dan toko-toko bangunan yang mewah mengelilingi rumah kediaman K.H. Muhammad Zaini Abul Ghani yang dikenal dengan komplek Sekumpul.

${ }^{4}$ M. Yusuf Kabul adalah orang yang dipercaya dan diizinkan oleh K. H. Muhammad Zaini Ghani memperbanyak kaset rekaman ceramah yang jumlahnya ribuan macam. M. Yusuf Kabul beralamat di Jl. P. Abdurrahman Kelurahan Keraton Martapura Kal-Sel. Telp (0511) 722160 Hp. 081349593599.
} 
tauhid/akidah, fikih dan tasawuf serta amaliyah, ${ }^{5}$ misalnya kitab tentang amaliyah yaitu al-Imdad fi Aurad abl al-Widad.

c. Terdapat beberapa ulama yang juga menjadi murid-murid setia K.H. Muhammad Zaini Abdul Ghani, seperti K.H. Ahmad Bakrie (alm), K.H. Zuhdiansyah, dan K.H. Asmuni (Guru Danau), saat ini memiliki ribuan jemaah dalam majelis taklimnya.

d. Ketika K.H. Muhammad Zaini Abdul Ghani masih hidup, pengajian yang dipimpin/dibinanya dihadiri puluhan ribu jamaah, baik kelompok pengajian pria maupun wanita, juga hampir semua santri yang menuntut ilmu di Martapura dan sekitarnya ikut dalam pengajian.

e. Ketika pengajian dimulai K.H. Muhammad Zaini Abdul Ghani turun dari rumah kediaman menuju musalla Ar-Raudah yang jaraknya sekitar 50 meter, jamaah berdesakan ingin bersalaman bahkan ada yang membawa anak-anak. Karena menurut keyakinan mereka, bersalaman dengan Abah Guru dapat membawa berkah. Akibatnya mereka berdesak-desakan hingga ada yang terjepit. Akibat peristiwa ini, dibuatlah pagar yang tembus pandang langsung ke depan musalla, agar jamaah dapat menyaksikan K.H. Muhammad Zaini Abdul Ghani, baik ketika berjalan menuju musalla ataupun ketika duduk di depan jamaah. Semua ini menunjukkan kecintaan masyarakat kepada K.H. Muhammad Zaini Abdul Ghani.

Di samping concern terhadap pengembangan agama, K.H. Muhammad Zaini Abdul Ghani juga sangat perhatian terhadap pengembangan seni-budaya seperti pembacaan syair maulid Habsyi. Bahkan di dalam pengajian rutinnya, syair maulid Habsyi selalu dibaca. Efek dari perhatiannya terhadap bidang ini, saat ini di Kalimantan Selatan, syair-syair maulid Habsyi berkembang pesat dan selalu dikumandangkan di berbagai tempat seperti di mesjid-mesjid, musalla

\footnotetext{
${ }^{5}$ Lihat Tim Al Zahra, al-Imdad fi Aurad abl al-Widad, (Martapura: Al Zahrra $1426 \mathrm{H})$.

${ }^{6}$ H. M. Arsyad (juru masak Komp. Sekumpul), "wawancara” Martapura, 5 Juli 2006.

${ }^{7} \mathrm{H}$. Miftahurrahman (Alumni Darussalam Martapura, murid $\mathrm{KH}$. Muhammad Zaini Abdul Ghani), "wawancara”, Martapura, 1 Juli 2006.
} 
dan di rumah-rumah, diiringi dengan tabuhan terbang, ${ }^{8}$ baik di bulan maulid maupun pada kegiatan keagamaan pada bulan-bulan lainnya.

Dalam hal keterkaitan perannya di dunia politik, dia selalu netral, tidak pernah ikut dalam kepengurusan parpol atau menyatakan mendukung salah satu partai tertentu. Sikap netralnya membuat siapa pun bisa datang berkunjung, bersilaturrahim kepadanya, bahkan semua orang yang datang di doakan agar sukses.

Ketakziman orang kepada Guru Sekumpul mulai dari tempat terdekat sampai terjauh, mulai rakyat sampai pejabat tinggi, mulai dari orang rasional sampai emosional, mulai dari lokal sampai nasional. Fakta ini menunjukkan betapa Guru Sekumpul mampu menembus batas geografis, psikologis dan sosiologis manusia. ${ }^{9}$

Ketika dia wafat, simpati masyarakat sangat besar kepada K.H. Muhammad Zaini Abdul Ghani, ketika berpulang ke rahmatullah terpampang ratusan karangan bunga sebagai ungkapan belasungkawa dari berbagai kalangan. Karangan bunga dari Presiden R.I Susilo Bambang Yodhoyono, Wapres Yusuf Kalla, Gubernur Kalimantan Selatan H. Rudy Ariffin, dan dari sejumlah pejabat, pengusaha, tokoh masyarakat dan lain-lain. Sementara itu, komunitas warga Banjar yang berada di Singapura, melalui tokohnya Muhammad Kasim bin Yahya, atas nama keluarga Banjar di Singapura menyampaikan ucapan duka mendalam atas kepergian K.H. Muhammad Zaini Abdul Ghani. ${ }^{10}$

Dalam paparan ini, penulis mengemukakan tentang K.H. Muhammad Zaini Abdul Ghani, telaah tentang karisma serta peran sosialnya dan tulisan ini diambil dari hasil penelitian ketika penulis menyusun disertasi. Tulisan ini diawali dengan pendahuluan, kemudian memaparkan karakteristik Martapura, riwayat hidup K.H. Muhammad Zaini Abdul Ghani, karisma serta peran sosialnya.

\section{Kondisi Geografis}

${ }^{8}$ Terbang/ rebana adalah gendang pipih bundar yang dibuat dari tabung kayu pendek dan agak lebar ujungnya, pada salah satu bagiannya diberi kulit. Lihat Departemen P dan K, Kamus Besar Bahasa Indonesia, (Jakarta: Balai Pustaka , 1995), cet. 4 edisi II, h.824.

'Sainul Hemawan, "Jejak Cinta Guru Sekumpul, in Memoriam K.H. Mubammad Zaini Abdul Ghani", Banjarmasin Post, 11 Agustus 2005, h. 20.

${ }^{10}$ Lihat ibid. 
Secara tradisional, Martapura adalah wilayah yang menggambarkan kepada penduduk yang mendiami wilayah di sepanjang sungai Martapura seperti sungai Batang, sungai Tuan, Lok Baintan, Karang Intan, Dalam Pagar, Astambul dan sebagainya. Daerah-daerah ini semuanya dikelilingi sungai-sungai, kecuali Simpang Empat Pengaron. Karena itu apabila menguraikan mengenai Martapura sekarang ini, berarti menjelaskan mengenai Martapura yang meliputi wilayah Kabupaten Banjar di Provinsi Kalimantan Selatan (Pintu gerbang kota Martapura).

Menurut Badan Pusat Statistik (BPS) Kabupaten Banjar tahun 2007, jumlah penduduk yang mendiami luas wilayah kabupaten Banjar secara keseluruhan adalah 464,148 orang, yang terdiri daripada 238,162 lelaki dan 225,986 perempuan. Jumlah penduduk terpadat adalah di kecamatan Martapura dengan kadar kepadatan 2042 penduduk per-km². Dibandingkan dengan tahun-tahun sebelumnya, Kecamatan Martapura mengalami kenaikan jumlah penduduk. Hal ini ditandai dengan meningkatnya kadar kepadatan penduduk, dimana pada tahun 2005, kepadatannya tercatat sebesar 2019 penduduk per-km². Kecamatan Peramasan hanya 6 penduduk per- $\mathrm{km}^{2}$ merupakan daerah dengan kadar kepadatan penduduk yang paling sedikit.

Dari keseluruhan jumlah penduduk yang mendiami daerahdaerah tersebut, 90 persen penduduknya adalah suku Banjar dan 10 persen lainnya adalah suku pendatang seperti Jawa, Bugis, Madura, Sumatera dan lainnya, yang merupakan penduduk minoritas. Di antara penduduk pendatang tersebut terdapat penduduk Arab keturunan yang cukup berpengaruh dalam kehidupan sosial keagamaan daerah ini. Sebagai penduduk yang berasal daripada keturunan Arab dan telah lama secara turun-temurun mendiami wilayah Martapura. Diperkirakan kedatangan mereka ke Martapura sekitar penghujung abad ke-19. Mereka umumnya berhijrah dari Hadramaut dan Hijaz. ${ }^{11}$ Pemukiman penduduk keturunan Arab ini terpusat di desa-desa Pekauman Ulu, Pekauman, Melayu Mekar, Antasan Senor, Kelurahan Pesayangan Utara, Kelurahan Jawa, dan Kelurahan Keraton ${ }^{12}$

\footnotetext{
${ }^{11}$ Kleden, Etos Kerja Pengrajin Batu Permata Banjar:Pendekatan Antropology (Jakarta: PMB- LIPI, 1996), h. 80.

${ }^{12}$ Anang Saifuddin, "Pemakaian Leksikon Bahasa Arab di Kalangan Komunitas Etnis Arab di Martapura”, Jurnal Penelitian, IAIN Antasari Banjarmasin, Vol. 9.
} 


\section{Karakteristik Sosial Keagamaan Masyarakat}

Martapura dikenal dengan julukan Serambi Mekkah ${ }^{13}$, karena situasi sosial dan kehidupan keagamaan masyarakatnya yang benar-benar menampakkan kehidupan religius. Kehidupan keagamaan di Martapura benar-benar mencerminkan suatu keyakinan agama yang baik, kemudian diekspresikan dalam bentuk ibadah dan kehidupan sosial keagamaan yang baik.

Agama memiliki tiga dimensi, yakni keyakinan, ibadah dan dalam bentuk interaksi dan interelasi sosial. Interaksi dan interelasi sosial inilah yang membentuk kelompok masyarakat religius, dimana pergaulan dan tata kehidupan diwarnai oleh jiwa agama. ${ }^{14}$

Martapura dapat dikatakan daerah agamis disebabkan beberapa peraturan daerah yang bersifat islami telah diimplementasikan. Dengan demikian, kesesuaian identitas Islam, perwujudannya dalam masyarakat Banjar adalah kenyataan. "Banjar adalah Islam dan Islam adalah Banjar". Dari sinilah, sesungguhnya identitas Islam sangat penting bagi masyarakat Banjar. Maka melestarikan ajaran Islam dalam masyarakat menjadi tanggung jawab bersama ulama dan umara. Terlebih lagi para ulama.

Kabupaten Banjar yang jumlah penduduknya sebanyak 464,148 orang merupakan pemeluk agama Islam, kecuali 314 pemeluk agama Kristen Protestan, 209 pemeluk agama Katholik, 101 pemeluk agama Hindu dan 98 pemeluk Buddha dan sebagian kecil masih ada Animisme. Jumlah rumah ibadah di daerah ini, terdiri atas 315 mesjid, 29 musalla, 924 langgar dan 31 buah pura dan lainnya. ${ }^{15}$

Mesjid terbesar yang menjadi simbol daerah Martapura adalah mesjid agung Al-Karamah yang diperkirakan sudah berusia 300 tahun lebih. Fisik bangunan ini semula terbuat dari kayu ulin kemudian diganti dengan bangunan beton.

Di samping banyak tempat ibadah, Martapura juga dikenal dengan daerah yang banyak membina Pondok Pesantren (Traditional

${ }^{13}$ Disebut serambi Mekah karena masyarakatnya yang agamis, banyak ulama dan santri, semarak dengan kegiatan keagamaan seperti salat berjamaah setiap waktu.

${ }^{14}$ Joachim Wach, Sociology of Religion, (Chicago: The University of Chicago Press, 1962), h 19-27.

${ }^{15}$ http://www. Banjarkab. go.id. 
Islamic Boarding School) yang secara keseluruhan berjumlah 35 buah dengan jumlah santri tidak kurang daripada 27,859 santri yang berada di pelbagai kecamatan di Martapura. ${ }^{16}$ Antara pondok-pondok pesantren tersebut, terdapat pondok pesantren yang sangat terkenal dan tertua di kota ini yaitu pondok pesantren Darussalam yang terletak di tepi sungai Martapura yang dibangun pada tanggal 14 Juli 1914 oleh K.H. Jamaluddin. Sebagai pondok pesantren terbesar di Kalimantan, (lihat lampiran: 4) lembaga ini telah memiliki program pendidikan untuk tingkat sarjana, yaitu Sekolah Tinggi Agama Islam (STAI) Darussalam. ${ }^{17}$

Dengan memiliki banyak pondok pesantren, maka tidaklah mengherankan apabila di daerah ini memiliki banyak ulama dan juga banyak santri. Kehidupan lingkungan masyarakat adalah masyarakat santri. Setiap saat terlihat para santri yang dalam kesehariannya menuntut ilmu dengan menggunakan kain sarung, baju koko dan memakai peci putih atau hitam.

Keberadaan santri juga menimbulkan suasana religius di tengah masyarakat, sebab masjid dan musalla menjadi makmur dengan kegiatan ibadah dan keagamaan. Para santri tersebut juga sering meramaikan tempat-tempat ibadah dengan pembacaan syair-syair maulid, seperti alDiba'i, al-Barzanji, al-Habsyi, Syaraf al-anam, Qasidah burdah dan sebagainya. Kebanyakan yang dibaca adalah syair maulid al-Habsyi yang telah dipopulerkan oleh K.H. Muhammad Zaini Abdul Ghani.

Para santri di Martapura dididik dalam suasana religiusitas. Mereka dibiasakan untuk selalu menghormati para ulama, guru, termasuk ulama yang mengarang kitab-kitab yang mereka pelajari sehari-hari. Karena itu, sikap hidup para santri sehari-hari adalah sam'an wa ta'atan (mendengar dan mentaati) bukan menilai dan mengkiritisi.

Dalam kondisi demikian kedudukan ulama sangat dihormati, baik di mata santri maupun masyarakat umum. Forum-forum ilmiah yang sifatnya mendiskusikan, mengkritisi, membanding dan meninjau ulang isi kitab ataupun pendapat para ulama tidak berkembang di Martapura dan sekitarnya. Kalau ada orang-orang yang mencoba mempertanyakan pendapat seorang ulama atau isi kitab, maka yang

\footnotetext{
${ }^{16}$ http://www.depag.go.id/data- pondok pesantren.

${ }^{17}$ http://www. Banjarkab.go.id
} 
lainnya akan menimpali: "pintar kitakah atau pintar guru/ulama". ${ }^{18}$ Apalagi kalau ulama yang dijadikan sorotan adalah ulama yang mereka idolakan, maka santri dan masyarakat yang menjadi jamaahnya siap pasang badan untuk membelanya. Akhirnya tradisi ilmiah tidak berkembang dan pemahaman keagamaan masyarakat berjalan secara tradisional dan hanya mengikuti pendapat guru atau ulama yang dijadikan rujukan. Kalaupun ada unsur modern, biasanya hanya dianut oleh kalangan mahasiswa atau cendekiawan yang sudah mau membuka wawasannya.

Daerah ini juga termasuk daerah yang paling banyak memiliki kumpulan majelis taklim untuk memperdalam ilmu-ilmu keislaman klasik. Diantara majelis taklim terbesar di daerah ini adalah majelis taklim Ar-Raudah yang bertempat di komplek Sekumpul dan dipimpin oleh seorang ulama kharismatik yaitu KH. Muhammad Zaini Abdul Ghani

Masyarakat di Kalimantan Selatan sering menyebutnya "Pengajian Sekumpul", hal ini disandarkan dengan nama tempat yakni Sekumpul dengan pimpinannya Guru Sekumpul ${ }^{19}$.

Di komplek Sekumpul tersebut, dibangun sebuah Musholla berukuran besar dan megah serta beberapa rumah kediaman, dan rumah K.H. Muhammad Zaini Abdul Ghani pribadi dan keluarga. Di musholla inilah K.H. Muhammad Zaini Abdul Ghani menyampaikan ceramah/pengajian keagamaan kepada puluhan ribu orang jamaah yang selalu menghadiri pengajian yang dilaksanakan setiap minggunya.

Aktivitas keberagamaan masyarakat di Kota Martapura dan sekitarnya dan di Kalimantan Selatan pada umumnya juga ditandai dengan seringnya dilakukan pembacaan manaqib yaitu menguraikan sejarah kehidupan (biografi) wali atau ulama tertentu. Pembacaan manaqib sering dilakukan dalam beberapa momentum seperti selamatan kelahiran anak, selamatan menyertai mandi-mandi bagi wanita hamil 7

${ }^{18} \mathrm{H}$. Shalihin Anwar, pensiunan guru bahasa Inggris MTsN Model Martapura dan tetangga K.H.M. Zaini Ghani di Sekumpul Marapura, "wawancara", Martapura, 5 Juni 2008.

${ }^{19}$ K.H. Muhammad Zaini Abdul Ghani memiliki nama lengkap K.H. Muhammad Zaini Abdul Ghani bin Abdul Ghani bin H. Abdullah bin Mufti H. M. Khalid bin Khalifah H. Hasanuddin bin Syekh Muhammad Arsyad Al-Banjari. Dia dilahirkan di Tunggul Irang, Martapura pada malam Rabu 27 Muharram $1361 \mathrm{H}$ atau 11 Februari 1942 M (Daudi, 2003, 144). Dia wafat pada hari Rabu tanggal 10 Agustus 2005 pagi sekitar jam 05.10 di kediamanannya Sekumpul Martapura. 
bulan, selamatan membangun atau menempati rumah baru, serta syukuran untuk memenuhi suatu nazar (qaul), serta syukuran karena beroleh nikmat atau rezeki tertentu. ${ }^{20}$

Keberagamaan masyarakat di Martapura dan sekitarnya juga ditandai dengan banyaknya pengajian tasawuf oleh para ulama, sehingga melahirkan ulama yang berpengaruh sebagai seorang sufi. Ulama yang mengajarkan tasawuf ini sebagai guru yang mesti ditiru dan diteladani dalam kehidupan sehari-hari, baik tingkah laku perbuatan maupun perkataan dan juga amaliyah ibadahnya. Pengajian tasawuf yang banyak dilaksanakan sifatnya adalah tasawuf amali atau akhlaqi yang sifatnya untuk memperbaiki akhlak dan mendekatkan diri kepada Allah dan sesama manusia. Sementara tasawuf falsafi tidak diajarkan secara terbuka, melainkan hanya diajarkan dalam lingkungan yang terbatas saja. Tasawuf falsafi dimaksud misalnya tentang ajaran Nur Muhammad, tentang wibdat al-wujud, wibdat al-sifat, wibdat al-asma, wibdat al-af'al, isyraq, dan sebagainya.

Dengan latar belakang kondisi demikian, maka pengajian tasawuf yang ramai di masyarakat adalah tasawuf amali yang bertujuan memperbaiki akhlak dan menghasilkan ketenangan batin. Tak hanya mengaji tasawuf amali, bahkan ada yang mendalaminya dengan menjalani tarekat dengan melakukan amalan zikir yang lebih intensif lagi. ${ }^{21}$

\section{Riwayat Hidup K.H. Muhammad Zaini Abdul Ghani}

\section{Latar Belakang Silsilah (Keturunan)}

K.H. Muhammad Zaini Abdul Ghani secara heriditas berasal dari garis keturunan (zuriat) ke-8 Muhammad Arsyad al-Banjari, ${ }^{22}$ seorang ulama besar dan penyiar Islam di Kalimantan Selatan.

K.H. Muhammad Zaini Abdul Ghani bin Abdul Ghani bin H. Abd. Manaf bin Muhammad Seman bin H. M. Sa'ad bin H. Abdullah bin 10 Juni 2008.

${ }^{20} \mathrm{Hj}$. Jamiyah Daiyah pengasuh majelis taklim di Banjarmasin, "wawancara",

${ }^{21}$ Tarekat yang banyak dipraktikkan di Martapura, Banjarmasin dan daerah lainnya di Kalimantan Selatan adalah Qadiriyah Naqsyabandiyah, Khalwatiyah, Syatariyah, Sammaniyah dan Alawiyah. Lihat M Laily Mansur, Tasamuf Islam Mengenal Aliran dan Ajaran, (Banjarmasin: Universitas Lambung Mangkurat, 1991), h.116-117.

${ }^{22}$ K.H. Muhammad Irsyad Zein ( Abu Daudi ), Ulama, "Wawancara", Martapura, 12 Mei 2008. 
Mufti H.M. Khalid bin Khalifah H. Hasanuddin bin Syekh Muhammad Arsyad Al-Banjari dilahirkan pada pukul 01.30 Wita pada malam Rabu 27 Muharram 1361 H. (11 Pebruari 1942 M) di kampung Tunggul Irang Martapura.

Sejak kecil K.H. Muhammad Zaini Abdul Ghani kecil diajarkan sikap disiplin, qana'ah ( menerima apa adanya), tidak suka mengadu, teliti, suka menolong, kaya akan cipta (kreatif). Akhlak mulia yang dimiliki Qusyairi juga tidak terlepas dari hasil didikan neneknya (Salabiah) yang selalu bercerita mengenai kehidupan Nabi dan Rasul serta orang-orang saleh di masa lalu. Setelah salat Isya, Qusyairi menuju tempat tidur, ditemani neneknya. Kemudian terdengarlah suara nenek Salabiah menidurkan cucunya dengan bacaan;

Ya Nafsiyat al-Salbiyah

Ma'a ni ma'nawiyah inna fi qalbi ghairullah

La ila ba illala bu Mubammad al-Rasulullah

Fi kulli lambatin wa nafasin 'adada ma wasi'abu ilmullab. ${ }^{23}$

\section{Pendidikan, Guru dan Murid}

Cita-cita tinggi dibarengi semangat yang tinggi pula serta usaha keras merupakan karakter K.H. Muhammad Zaini Abdul Ghani. Pada tahun 1949, dia masuk Pesantren Darussalam Martapura berjarak satu kilometer dari rumah. Ia pergi bersama-sama kawan santri lainnya. Setiap pagi membawa kitab yang didekap di dada, ini kebiasaan atau cara santri di Darussalam Martapura. ${ }^{24}$

Pada tahun 1949 saat berusia 7 tahun, dia mulai mengikuti pendidikan formal masuk ke Madrasah Ibtidaiyah Darussalam, Martapura. Nama yang dicantumkan sebagai santri adalah Muhammad Zaini. Pada masa ini dia sudah belajar dengan guru-guru terkenal yang spesialis dalam bidang keilmuan sampai ke tingkat Aliyah. Guru-gurunya ini adalah tokoh-tokoh besar yang sudah tidak diragukan lagi tingkat keilmuannya misalnya K.H. Husin Qadri pengarang buku "Senjata Mukmin" yang banyak dicetak di Kalimantan Selatan dan tersebar ke beberapa daerah lainnya di luar Kalimantan Selatan. Kemudian al-Alim al-Allamah Seman Mulya, dan Syekh Salman Jalil, Seman Mulya adalah

${ }^{23}$ Ibid., h. 54.

${ }^{24}$ H. A. Djazouly Seman, “Wawancara”, Martapura, 25 Mei 2008. 
paman K.H. Muhammad Zaini Abdul Ghani yang secara intensif mendidiknya baik ketika berada di sekolah maupun di luar sekolah.

Selain itu, di antara guru-guru K.H. Muhammad Zaini Abdul Ghani adalah Syekh Syarwani Abdan (Bangil) dan al-Alim al-Allamah alSyekh Al-Sayyid Muhammad Amin Kutbi. Kedua tokoh ini biasa diangap guru khususnya, atau meminjam istilah yang dia buat yaitu Guru Suluk (Tarbiyyat al-Sufiyah). Beberapa gurunya yang lain adalah Kyai Falak (Bogor), Syekh Yasin bin Isa Padang Syekh Hasan Masyath, Syekh Ismail Al-Yamani, dan Syekh Abdul Kadir Al-Bar. Sedangkan guru pertama secara ruhani adalah al-Alim al-Allamah Ali Junaidi (Berau) bin al-Alim al-Allamah Qad\}i Muhammad Amin bin al-Alim al-Allamah Mufti Jamaluddin bin Syekh Muhammad Arsyad Al-Banjari. Selain itu, masih banyak tokoh lagi, gurunya ada sekitar 179 orang sepesialis bidang keilmuan Islam terdiri dari wilayah Kalimantan, Jawa, Madura, dan dari Mekkah

Di antara guru-guru Muhammad Zaini Abdul Ghani yang sangat mempengaruhi kepribadian dan kecintaan terhadap ilmu di antaranya adalah

1) Al-'A im al-Fadil Guru Sulaiman

2) Al-'A lim al-Fadil Guru Haji Abdul Hamid Husein

3) Al-'A lim al-Fadil Guru Haji Mahalli Abdul Qadir

4) Al-'A lim al-Fadil Guru Haji Muhammad Zein

5) Al-'A lim al-Fadil Guru Haji Muhammad Rafi'i

6) Al-'A lim al-Fadil Guru H.M. Husein Dahlan

7) Al-'A lim al-Fadil Guru Syahran

8) Tuan Guru H. Muhammad Syarwani Abdan. ${ }^{25}$

\section{Wafatnya}

Setelah sempat dirawat selama lebih kurang 10 hari di rumah sakit Mount Elizabeth Singapura, karena penyakit ginjal yang diderita, pada hari Rabu, 5 Rajab 1426 H. bertepatan dengan 10 Agustus 2005,

${ }^{25}$ M. Khairuddin, Murid K.H. Muhammad Zaini Abdul Ghani, "Wawancara" ,Banjarmasin. 20 Mei 2008. 
jam 05.10 pagi dia berpulang ke rahmatullah menghadap Allah swt. dalam usia 63 tahun. Dia meninggalkan tiga orang istri yaitu $\mathrm{Hj}$. Juwairiyah, Hj. Laila dan $\mathrm{Hj}$. Siti Noor Jannah serta dua orang anak yakni; Muhammad Amin Badali al-Banjari dan Muhammad Hafi Badali al-Banjari.

Seluruh masyarakat Kalimantan merasa kehilangan seorang Tuan Guru yang menjadi panutan, penerang, dan penyuluh kehidupan umat. Kini umat Islam di Martapura dan Kalimantan Selatan umumnya, menantikan kembali hadirnya generasi baru, ulama panutan yang akan menggantikan atau paling tidak memiliki karisma dan ilmu sebagaimana yang dimiliki oleh Guru Sekumpul, untuk memimpin dan membimbing umat menuju kedamaian di bawah rida Allah swt. ${ }^{26}$

Jenazah K.H. Muhammad Zaini Abdul Ghani dishalatkan sebanyak 35 kali sebelum zuhur sebnyak 11 kali dan setelah Zuhur sampai azan waktu Ashar sebanyak 24 kali. Pelayat yang datang berjumlah ratusan ribu orang.

Meski demikian, murid K.H. Muhammad Zaini Abdul Ghani yang jumlahnya puluhan ribu orang memberi warna tersendiri dalam kehidupan keberagamaan di Kalimantan Selatan

\section{Karya Tulis}

Selama hidup, Tuan Guru K.H. Muhammad Zaini Abdul Ghani telah menulis beberapa buah kitab, antara lain:

1) Al-Risalat al-Mubarakah.

2) Manaqib al-Sayyid Muhammad ibn 'Abd al-Karim al-Qadiri al-Hasani al-Samman al-Madani.

3) Al-Risalat al-Nuraniyyah fi Syarh al-Tawassulat al-Sammaniyyah.

4) Nubzat fi Manaqib al-Imam al-Masybur bi al-Ustaz al- A'zam Muhammad Ibn 'Ali Ba'lawiy.

Dia juga sempat memberikan beberapa pesan:

1) Menghormati ulama dan orang tua;

2) Baik sangka terhadap muslimin;

${ }^{26} \mathrm{H}$. Muhammad Irsyad Zein (Abu Daudi), Ulama, "Wawancara", Martapura, 12 Mei 2008 
3) Murah hati;

4) Murah harta;

5) Manis muka;

6) Jangan menyakiti orang lain;

7) Mengampuni kesalahan orang lain;

8) Jangan bermusuh-musuhan;

9) Jangan tamak atau serakah;

10) Berpegang kepada Allah, pada kabul segala hajat;

11) Yakin keselamatan itu pada kebenaran.

\section{Karisma K.H. Muhammad Zaini Abdul Ghani}

Menurut Weber pengertian karisma adalah "charisma" will be applied to a certain quality of an individual personality by virtue of which he is set apart from ordinary men and treated as endowed with supernatural, superhuman, or at least specifically exceptional powers or qualities. These are such as are not accessible to the ordinary person, but are regarded as of a divine origin or as exemplary, and on the basis of them the individual concerned is treated as a leader. ${ }^{27}$

Istilah karisma digunakan terhadap sifat tertentu pada seseorang yang karenanya orang tersebut dibedakan dengan orang biasa dan dipandang mendapat kekuatan adikodrati, adimanusiawi atau paling tidak luar biasa kekuatannya sedemikian rupa sehingga tidak terjangkau oleh orang biasa tetapi dianggap sebagai/berasal dari Tuhan, atau sebagai teladan dan atas dasar itu individu tersebut diperlakukan sebagai seorang pemimpin. $^{28}$

Weber menegaskan karisma suatu sifat tertentu dari suatu kepribadian seorang individu berdasarkan mana orang itu dianggap luar biasa dan diperlakukan sebagai seorang yang mempunyai sifat-sifat gaib,

${ }^{27}$ Max Weber, The Theory of Social and Economic Organization, trans. A. M. Henderson and Talcott Parsons (New York: The Falcon's Wing Press, 1947), h. 358-359.

${ }^{28}$ Bryan Wilson, loc. cit., lihat David L. Sills, loc. cit., lihat Joachim Wach, Sociology of Religion (Chicago: The University of Chicago Press, 1962), h. 337 - 341. Lihat Thomas F. O. Dea, The Sociology of Religion, diterjemahkan oleh Tim Penterjemah Yasogama dengan judul Sosiologi Agama suatu Pengenalan Awal, (Jakarta: Rajawali Press, 1990), h. 44. 
sifat unggul atau dengan kekuatan-kekuatan yang khas dan luar biasa. Seorang pribadi berkarisma adalah bahwa dia seorang yang luar biasa yang sangat mengesankan yang sering dipikirkan dari suatu jenis gaib, yang membuat dia berbeda dari yang biasa. Kemudian yang lebih penting adalah ada sifat-sifat yang luar biasa yang dianggap oleh orang lain sebagai atribut dari orang tersebut. ${ }^{29}$

Karisma merupakan fenomena, ia muncul dalam situasi tertentu, terutama dalam kondisi yang menggembirakan, penuh gejolak, atau kondisi sulit. Dalam tulisan Weber tidak ada petunjuk pelenyapannya secara sosial. Eksistensi dan durasi kekuatan karisma tergantung pada respons pihak lain. Untuk mempengaruhi hati dan pikiran orang lain, orang berkarisma harus terus menunjukkan dan membuktikan keajaibannya. Karisma dalam bentuknya yang paling murni hanya eksis sementara. Karena karakteristik personalnya karisma sulit diwariskan, setelah orang yang punya karisma meninggal. Memang karisma itu akan lenyap dan menjadi "rutin" melalui institusi berorientasi tradisional atau legal melalui monarki atau jabatan, ada istilah karisma jabatan dan karisma temurun. ${ }^{30}$

Karisma adalah kualitas tertentu seorang individu yang menyebabkan dirinya berbeda dengan orang lain, orang yang dikaruniai sifat adikodrati, adimanusiawi atau paling tidak kekuatan atau kualitas yang luar biasa, walaupun mereka tidak pernah menyatakan dirinya memiliki anugerah tersebut. ${ }^{31}$

Sesuai dengan pengertian di atas, K.H. Muhammad Zaini Abdul Ghani juga di pandang memiliki karisma. Hal ini dapat dilihat dari indikator sebagai berikut:

\section{Kesan Para Ulama, Pejabat dan Tokoh Masyarakat}

${ }^{29}$ Max Weber, loc. cit., Anthony Giddens, Capitalism and Modern Social Theory: an Analysis of Writing of Marx, Durkheim and Max Weber, diterjemahkan oleh Shoeheba Kramadibrata dengan judul; Kapitalisme dan Teori Sosial Modern: Suatu Analisa Terbadap Karya Tulis Marx, Durkheim dan Max Weber, (Jakarta: UI-Press, 1986), h. 197.

${ }^{30}$ Max Weber, loc. cit.,William Authwaite (Ed.), op. cit., h.93. Lihat Bryan S.Turner, Weber and Islam, diterjemahkan oleh G.A. Ticoalu, Sosiologi Islam: Suatu Telaah Analisa atas Tesa Sosiologi Weber, (Jakarta: CV. Rajawali, 1984), h. 37.

${ }^{31}$ Musafir Pababbari, Islam dan Politik Lokal Studi Sosiologis atas Tarekat Qadiriyah di Mandar (Makassar: Padat Daya, 2009), h. 60. 
Ulama, pejabat dan tokoh masyarakat punya kesan masingmasing dan memuji beberapa kelebihan K.H. Muhammad Zaini Abdul Ghani. Di antaranya adalah:

K.H. Asywadie Syukur Ketua MUI Provinsi Kalimantan Selatan, memandang bahwa sosok K.H. Muhammad Zaini Ghani adalah insan panutan, sejak kecil sudah tampak keteladanannya. Di Kalimantan Selatan memang banyak ulama, akan tetapi tidak seperti dia. Apa yang diucapkan dijadikan pedoman oleh kaum muslimin dan muslimat terutama dalam kehidupan bermasyarakat. ${ }^{32}$

H. Amidhan Ketua MUI pusat menyatakan dengan berpulangnya K.H. Muhammad Zaini Abdul Ghani ke rahmatullah berarti masyarakat kehilangan tokoh besar, tidak saja bagi umat Islam Kalimantan Selatan, tetapi Indonesia. Guru sekumpul adalah ulama yang mampu menjembatani antara pemerintah dan rakyat dan tidak bisa dibeli oleh penguasa. Umat Islam kehilangan ulama karismatik. Ceramahnya sangat mempengaruhi umat, banyak orang rela mengeluarkan uang banyak dengan membeli rumah dekat dengan Guru Sakumpul agar setiap saat mendengarkan ceramah. ${ }^{33}$

H. G. Rusdi Effendi. AR pemimpin Banjarmasin Post Group mengatakan bahwa belum ada figur sekarisma Guru Sekumpul, dan sangat sulit untuk mencari penggantinya, masyarakat sangat kehilangan. Semasa hidup bila ada persoalan yang menyangkut pers secara otomatis Guru Sekumpul memanggil. ${ }^{34}$

H. Muhammad Said, tokoh masyarakat dan mantan Gubernur Provinsi Kalimantan Selatan menyatakan bahwa Guru Sekumpul adalah pendingin antar kelompok masyarakat terutama di Kalimantan Selatan, sehingga kesannya semasa hidup selalu netral dalam dunia politik. Siapa saja yang datang bersilaturrahim berkunjung ke tempatnya, pasti diterima dengan tangan terbuka dan selalu diingatkan tentang perlunya rukun dalam kehidupan ini, diharapkan ulama-ulama meniru hal ini, mampu

\footnotetext{
${ }^{32}$ Redaktur" Kesan Mereka Terhadap Guru Sekumpul", Banjarmasin Post, Kamis 11 Agustus 2005/ 6 Rajab 1426 H.

${ }^{33}$ Lihat Redaktur" Kesan Mereka Terhadap Guru Sekumpul", Banjarmasin Post, Kamis 11 Agustus 2005/ 6 Rajab 1426 H.

${ }^{34}$ Lihat Redaktur" Kesan Mereka Terhadap Guru Sekumpul”, Banjarmasin Post, Kamis 11 Agustus 2005/ 6 Rajab 1426 H.
} 
mendinginkan setiap ada kejadian dan perbedaan serta dapat memberikan petuah-petuah yang menyejukkan. ${ }^{35}$

Gubernur Kalimantan Selatan H. Rudy Ariffin menyatakan, rakyat Kalimantan Selatan kehilangan dan sangat berduka. Sejak K.H. Muhammad Zaini Abdul Ghani sakit, gubernur selalu memperhatikan, bahkan ketika berangkat dan pulang berobat ke rumah sakit Mount Elizabeth Singapura H. Rudy Ariffin selalu mendampingi. ${ }^{36}$ H. Rudy Ariffin sejak menjabat sebagai Bupati Kabupaten Banjar dinyatakan sebagai anak angkat oleh K.H. Muhammad Zaini Abdul Ghani; " ikam jadi anak angkatku dunia dan akhirat", (kamu H. Rudy Ariffin jadi anak angkat saya dunia akhirat). Menurut H. Rudy Ariffin, dia adalah ulama yang sangat dihormati dan disegani. Dia tempat meminta nasihat dan pertimbangan berbagai pikiran, dorongan dan dukungan, menjadi motivasi dalam berbagai hal. Dia menjadi kompas yang bisa menunjukkan arah jika ingin melangkah. ${ }^{37}$

K.H. Anang Djazouly Seman (ulama dan salah seorang Paman dari K.H. Muhammad Zaini Abdul Ghani) menyatakan Guru Sekumpul adalah ulama yang memiliki kelebihan-kelebihan dibandingkan dengan ulama-ulama lainnya. Para ulama mengajarkan ilmunya apa yang didapatkan dari guru-guru yang telah mengajarnya, tetapi Guru Sekumpul mengajarkan ilmu yang didapatkan dari guru-guru, tetapi juga mendapatkan ilmu dari langit, yakni secara "ladunni". K.H. Muhammad Zaini Abdul Ghani adalah ulama yang patut diteladani. Ia sebagai salah seorang "warasatul anbiya"(pewaris para nabi) yang menyampaikan amanah para nabi dan diikuti oleh jutaan jamaah.

Masih banyak komentar tokoh agama dan masyarakat yang tidak bias penulis cantumkan pada tulisan ini.

\section{Tamu Yang Berkunjung ke Sekumpul.}

Sejak K.H. Muhammad Zaini Abdul Ghani bertempat di Sekumpul, sudah tidak terhitung banyaknya tamu yang berkunjung, mulai

${ }^{35}$ Lihat Redaktur" Kesan Mereka Terhadap Guru Sekumpul”, Banjarmasin Post, Kamis 11 Agustus 2005/ 6 Rajab 1426 H.

${ }^{36}$ Lihat Redaktur" Kesan Mereka Terhadap Guru Sekumpul”, Banjarmasin Post, Kamis 11 Agustus 2005/ 6 Rajab 1426 H.

${ }^{37}$ Ahmad Rosyadi, Bertamu Ke Sekumpul, (Cet. III Yokyakarta, PT. LKiS Pelangi Aksara, 2004 ), h. xx. 
dari artis, pejabat Negara, pejabat lokal, petinggi militer, hingga para menteri, presiden dan wakil presiden. Dari luar negeri seperti Yaman, Hadramaut, Malaysia, Brunei Darussalam. Gubernur Diraja Malaysia, Dato Pangeran Haji Muhammad Ya'kup. Menteri Agama (Mufti) Negeri Perak, Dato Seri Haji Harusani bin Haji Zakaria pada tanggal 20 Juli tahun $2001 .^{38}$

Di kalangan militer, terutama yang bertugas di Pangdam VI Tanjungpura selalu bersilaturrahim. Tercatatlah nama Mayor Jenderal TNI Namuri Anoem, Mayjen TNI Z.A. Maulani, Mayjen TNI Muchdi Purwo Pranjono, Mayjen TNI Yacop Dasto, Mayjen TNI Sang Nyoman Suwisma, Mayjen TNI Zainuri Hasyim, Mayjen TNI Joko Besariman, Mayjen TNI Hadi Waluyo, Mayjen TNI Herry Cahyana, dan lain-lain. Pejabat militer lainnya tercatat Kepala Staf Angkatan Darat TNI (KASAD), Jenderal TNI Hartono, Kasospol TNI Letnan Jenderal TNI Syarwan Hamid, Danpuspom TNI Djasrie Marien dan lain-lain. ${ }^{39}$

Para menteri seperti; Ali Said SH, Harmoko, Hartono, Wardiman Djojonegoro, Marzuki Usman, Muslimin Nasution, Fahmi Idris, Tholhah Hasan, Said Agil Husein Al-Munawwar, Wiranto, Jaksa Agung MA Rachman, Alwi Shihab, Syamsul Mu'arif, Ali Marwan Hanan, Sri Sultan Hamengkubowono X, Akbar Tandjung, H. Tarmizi Taher, Siti Hardiyanti Indra Rukmana, Ismail Hasan Metareum. ${ }^{40}$

Presiden Megawati Soekarnoputri, Presiden Abdurrahman Wahid (Gus Dur) dan Wakil Presiden Hamzah Haz. Hamzah Haz ketika hari berpulang ke rahmatullah K.H. Muhammad Zaini Abdul Ghani, dia datang bertakziah, larut dalam duka bersama masyarakat Kalimantan Selatan dalam upacara pemakaman. ${ }^{41}$

Dari Kalangan kepolisian, baik yang bertugas di Kalimantan Selatan, Kapolda atau Kapolres dan petinggi Polri di Jakarta, Brigjen Soni Harsono, Brigjen Pol H. Mudji Hardjadi, Brigjen Pol H. Basyir Ahmad

\footnotetext{
${ }^{38}$ Rosyadi, Bertamu Ke Sekumpul, h. 23.

${ }^{39}$ Rosyadi, Bertamu Ke Sekumpul, h. 24.

${ }^{40}$ Rosyadi, Bertamu Ke Sekumpul, h. 24.

${ }^{41}$ Redaktur, "Belum Ada Tandingannya", Banjarmasin Post, Kamis, 11
} Agustus 2005/6 Rajab 1426 H. 
Barmawi, Brigjen Pol Sumantyawan HS, Kapolri Da’i Bachtiar datang bersilaturrahim ke Sekumpul. ${ }^{42}$

Tamu dari kalangan artis, tercatat; Harry Mukti, Ulfa Dwiyanti, Sarah Azhari, Ayu Azhari, Chrisye, Iis Dahlia, Camelia Malik, Emha Ainun Najib, Novia Kolopaking, Haddad Alwi, Sulis, Elvi Sukaesih, Tietik Sandhora, Muchsin Alatas, Nia Daniaty, Inneke Koesherawaty, Anita Dahlan, Dono, Kasino, Indro, Timbul, Doyok, Kadir, Noor Tompel, Tarzan, Basuki, Inul Daratista dan lain-lain. ${ }^{43}$

Di kalangan figur publik, Arie Sigit (cucu Presiden Soeharto), Ais Anantama Said (putra Ali Said SH),Isfan Fajar Satyo (putra Wapres Try Sutrisno), K.H. Zainuddin MZ, K.H. Muhammad Syukron Makmun, K.H. Hasyim Muzadi, K.H. Cecep Saipuddin, K.H. Muhammad Arifin Ilham, K.H. Abdullah Gymnastiar (Aa Gym). ${ }^{44}$

\section{Beberapa kejadian atau cerita yang dipandang oleh sebagian masyarakat sebagai karamah}

Dalam perspektif akademik, kejadian yang seringkali bertentangan dengan logika selalu diupayakan untuk dicerna dan ditelaah secara ilmiah. Hal ini berbeda dengan mayoritas masyarakat awam, apalagi para murid yang menjadi pengikut setia sang mursyid/guru.

K.H. Muhammad Zaini Abdul Ghani juga dipandang memiliki keunikan yang dipandang oleh para pengikutnya atau sebagian masyarakat Banjar sebagai sebuah karamah. Seperti halnya cerita yang terdapat di dalam riwayat kehidupan tokoh sufi atau para wali, maka di dalam dinamika dan kehidupan K.H. Muhammad Zaini Abdul Ghani pun juga mengalami hal serupa.

Dalam kaitan ini, K.H. Muhammad Zaini Abdul Ghani telah mengingatkan kepada masyarakat untuk tidak begitu saja mempercayai hal-hal "gaib/aneh" sebagai sebuah karamah. Dia berpesan agar masyarakat jangan sampai tertipu dengan segala keanehan dan keunikan yang dianggap sebagai karamah. Karena bagaimanapun juga karamah menurutnya adalah anugerah, murni pemberian, bukan suatu keahlian atau skill. Karena itu, jangan pernah berpikir atau berniat untuk

\footnotetext{
${ }^{42}$ Rosyadi, Bertamu Ke Sekumpul, h. 24.

${ }^{43}$ Rosyadi, Bertamu Ke Sekumpul, h. 25.

${ }^{44}$ Rosyadi, Bertamu Ke Sekumpul, h. 25.
} 
mendapatkan karamah dengan melakukan ibadah atau wiridan-wiridan. Karamah yang paling mulia dan tinggi nilainya adalah istiqomah di jalan Allah itu sendiri. Kalau ada orang mengaku sendiri punya karamah tetapi shalat ibadahnya tidak beres, maka itu bukan karamah.

Lebih jauh dia menyatakan bahwa karamah bukanlah pertanda penting bagi keshalehan seseorang, tetapi konsistensi dalam berbuat kebaikan, jauh lebih baik daripada seribu karamah. Dengan demikian mencintai guru bukan berarti memujanya bagai dewa, akan tetapi mengamalkan kebaikan-kebaikan yang diajarkannya45.

Meski demikian, karena faktor kecintaan, kesetiaan, lingkungan bahkan pendidikan bahkan pendidikan, maka sejumlah cerita "unik" tersebut tetap menjadi sebuah fakta di dalam masyarakat. Sebagian masyarakat terutama para murid dan pengikut setianya percaya bahwa cerita tersebut merupakan sebuah realitas yang benar-benar pernah terjadi.

Meski demikian, kepercayaan seperti ini bukan menjadi sebuah representasi dari komunitas masyarakat Banjar pada umumnya disebabkan perbedaan perspektif dalam memandang hakikat sebuah karamah.

Dari hasil interview terhadap sejumlah akademisi IAIN Antasari yang penulis lakukan dapat disimpulkan bahwa pada dasarnya mereka meyakini akan adanya karamah, hanya saja bentuk karamah tersebut tidak seluruhnya sama dengan pandangan masyarakat awam. Dengan demikian penulis berkesimpulan bahwa terdapat perbedaan perspektif tentang hakikat karamah antara masyarakat awam, pengikut setia/murid dengan para akademisi/ilmuwan. Masyarakat awam memandang karamah sebagai sebuah kejadian "aneh" yang terkadang berada di luar jangkauan logika. Sementara akademisi/ilmuwan lebih memandang karaman sebagai sebuah kelebihan dari sisi peran sosial, kultural, keagamaan dan kemampuan menginternalisasikan nilai-nilai yang dimilikinya ke dalam kehidupan masyarakat.

\section{Peran Sosial K.H. Muhammad Zaini Abdul Ghani}

\section{Keagamaan dan Dakwah}


K.H. Muhammad Zaini Abdul Ghani lebih dikenal dengan dakwah lisan dan dakwah bilhal. Dakwah tulisan Guru Sekumpul di antaranya, Manakib Al-Syekh al-Sayyid Mubammad Ibn 'Abd al-Karim alQadiri al-Hasan al-Samman al-Madani, al-Risalat al-Nuraniyyah fi Syarb alTawassulat al- Sammaniyab. ${ }^{46}$

Sejak K.H. Muhammad Zaini Abdul Ghani menetap di Sekumpul, terjadilah perubahan secara mendasar dan besar-besaran terhadap daerah Sekumpul dan sekitarnya, masyarakat juga berlomba ikut membeli tanah di sana, tujuannya tidak lain agar tempat tinggal mereka dekat dengan Guru. Tidak hanya para murid dekat Guru Zaini yang ikut hijrah, akan tetapi murid dari berbagai daerah pun juga ikut berhijrah, misalnya dari Banjarmasin dan beberapa kabupaten yang ada di Kalimantan Selatan, bahkan ada juga dari daerah lain, seperti dari Samarinda (Kalimantan Timur), Sampit (Kalimantan Tengah), dan lainlain. $^{47}$

Pengajian Sekumpul diikuti oleh orang-orang yang berusia ratarata antara 12 hingga 60-an dengan latar belakang pendidikan dan pekerjaan yang berbeda-beda, mulai dari santri, mahasiswa, dosen, pedagang, pegawai negeri dan swasta, petani, pensiunan, guru agama, bahkan pejabat pemerintahan. Jadwal pengajian untuk wanita berbeda dengan pria. Pengajian diikuti oleh puluhan ribu jamaah. Penekanan yang paling utama adalah menyampaikan ajaran akidah (keimanan), keyakinan kepada Allah dengan paham yang dibawa oleh Abu Mansur alMaturidi dan Abu al-Hasan al-Asy'ari. Tentang syariat, berbentuk ibadah maupun muamalah yang berkaitan dengan permasalahan kehidupan menurut paham Imam al-Syafi'i. Kemudian ajaran tasawuf berupa etika/akhlak penganut sufisme Imam Ghazali. ${ }^{48}$

\section{Mengembangkan Tarekat Samaniyah}

Diperkirakan bahwa tarekat ini dibawa oleh Syekh Muhammad Arsyad karena semasa belajar bersama-sama dengan Al-Palimbani,Abd al-Rahman Al-Batawi, Abd al-Wahab Al-Bugisi belajar dengan Syekh AlSamman Al-Madani. Maka menariknya adalah tarekat ini sesungguhnya

${ }^{46}$ Mujiburrahman, Mencintai Guru, Banjarmasin Post 6 Juni 2011

${ }^{47}$ H. Fathurrahman Azhari, PNS, Dosen IAIN Antasari, "Wawancara", Sekumpul Martapura, 11 Mei 2008.

${ }^{48}$ H. Fathurrahman Azhari, PNS, Dosen IAIN Antasari "Wawancara", Sekumpul Martapura, 11 Mei 2008. 
merupakan bahagian daripada kecenderungan tasawuf yang berhaluan wahldat al-wujûd, sebagaimana yang tergambar dalam syatâhat-syatâhat yang terkandung dalam Râtib Sammân, kemungkinan besar gambaran umum yang terdapat dalam Risâlah yang ditulis oleh Syekh Muhammad Arsyad itu merupakan ajaran-ajaran mengenai adab dan zikir daripada tarekat Samaniyah yang telah disederhanakan. Penyederhanaan ini berlaku untuk menyesuaikan dengan konteks daerah.

Perkiraan ini semakin kuat karena K.H. Muhammad Zaini Abdul Ghani, salah satu di antara keturunan Syekh Muhammad Arsyad Al-Banjari yang paling berpengaruh dan dihormati di Kalimantan Selatan, sangat berperan sekali dalam menghidupkan tarekat tersebut di kawasan ini. ${ }^{49}$ Tarekat ini dihidupkan oleh tokoh yang sering disebut dengan Guru Sekumpul di Martapura ini melalui karyanya al-Risâlat al-Nurâniyyah fì syarb al-tawashshulât al-sammâniyyah dalam majlis pengajian Ar-Raudah Sekumpul Martapura.

Tarekat Sammaniyah mendapat sambutan yang luar biasa dan banyak pengikutnya dari masyarakat muslim Kalimantan Selatan, karena K.H. Muhammad Zaini Abdul Ghani mengenalkan dan mengijazahkan kepada murid-murid di pengajian Ar-Raudah Sekumpul. Pemberian ijazah ini dilaksanakan pada setiap kali pengajian. Akan tetapi pada masamasa akhir tidak lagi memberikan ijazah, namun mengizinkan bagi siapa yang ingin mengamalkan. ${ }^{50}$

\section{Memasyarakatkan Pembacaan Maulid Al-Habsyi}

K.H. Muhammad Zaini Abdul Ghani, telah memasyarakatkan pembacaan Maulid Habsyi, terutama di wilayah Kalimantan yaitu; seluruh Kalimantan Selatan, sebahagian Kalimantan Tengah, dan Kalimantan Timur.

Dalam hal izin membacakan Maulid Habsyi, K.H. Muhammad Zaini Abdul Ghani memperoleh dengan dua jalan. Pertama, dari Habib Zein bin Muhammad Al-Habsyi, salah seorang murid pengarang. Kedua, dari Habib Anis Solo, cucu dari pengarang, pada tahun $1966 .{ }^{51}$ Tentang

${ }^{49}$ H.A. Athaillah," Perkembangan Tarekat Sammaniyah di Kalimantan Selatan", Khazanah, Vol. III, No 2, April 2004, h. 227.

${ }^{50}$ Athaillah," Perkembangan Tarekat Sammaniyah, h.228.

51Athaillah," Perkembangan Tarekat Sammaniyah, h.228. 
pembacaan maulid Habsyi ini K.H. Muhammad Zaini Abdul Ghani telah mendapat ijazah dan melalui sanad di atas. ${ }^{52}$

Di musalla Ar-Raudah ini biasanya diadakan pengajian kitab ilmu tauhid, fikih dan tasawuf diadakan juga Maulid Habsyi (malam senin), dan salawat Burdah (malam jum'at) yang masih berjalan hingga sekarang, majlis Burdah dan pembacaan Maulid al-Habsyi.

Pembacaan Maulid Habsyi bukan saja dibaca pada setiap kali peringatan maulid nabi besar Muhammad saw. Pada bulan Rabiul Awwal. Tetapi dalam berbagai upacara keagamaan sering sebelum acara inti, sebelumnya acara pembacaan Maulid Habsyi, seperti acara pernikahan, sunatan, tasmiyah (pemberian nama seorang anak), pengantaran jujuran, berangkat haji, acara arisan yasinan, dan lain-lain. ${ }^{53}$

Bahkan ada secara rutin dilaksanakan pembacaan maulid ini di rumah-rumah tertentu, di musalla-musalla, di mesjid-mesjid. Biasanya satu kali dalam seminggu, hal ini untuk pendidikan dan latihan sekaligus memasyarakatkan. Sekarang sangat pesat perkembangannya. Group atau kelompok pembacaan maulid ini tumbuh bagaikan jamur. Menurut Ahmad Supian di Kalimantan selatan ada ribuan group maulid Habsyi ini. Sedangkan khusus di Kabupaten Banjar saja tercatat sebanyak 166 buah $^{54}$.

Group Maulid Habsyi yang tersebar, baik di tingkat kecamatan maupun di desa, semua menggunakan alat rebana (terbang) berukuran kecil dan besar. Maulid Habsyi kombinasi pembacaan salawat atas Nabi Muhammad saw. dan juga ada unsur seni islami. ${ }^{55}$

Propinsi Kalimantan Selatan pernah menyelenggarakan festival Maulid Habsyi, pada tanggal 4 sampai 11 April 2010 di Banjarmasin. Final festival Maulid Habsyi yang di gelar pemerintah Kalimantan Selatan dan di dukung oleh Dealer Honda, Banjarmasin Post Group, dilaksanakan di Halaman Radio Republik Indonesia (RRI) Banjarmasin, Minggu (11/4/2010). Sebelumnya penyelenggaraan Festival ini dimulai

${ }^{52}$ Muhammad Zaini Abdul Ghani, Majmu' Ba'd al-Asanid Ma'a al-Ijazah, (Sekumpul Martapura: Penerbit ar-Raudhah, t.th.), h. 5-6.

${ }^{53}$ H.M. Ilyas, Ulama (PNS), "Wawancara", Banjarmasin, 8 Mei 2008

${ }^{54}$ Ahmad Supian, (PNS, Guru agama M.Ts.N), "Wawancara”, Banjarmasin, 5 Mei 2008

${ }^{55}$ Ahmad Supian, (PNS, Guru Agama M.Ts.N), "Wawancara”, 5 Mei 2005 
Minggu, (4/4/2010) di halaman Mesjid Raya Sabilal Muthadin dengan peserta 340 kelompok dan telah berhasil memecahkan rekor Muri dengan peserta terbanyak di Indonesia, yakni sebanyak 7.222 orang dengan melantunkan Selawat serentak. Ribuan orang ikut menyaksikan Grand final Festival Maulid ini. Di Jalan A. Yani Km. 2 terlihat macet dan padat yang dijejali pengunjung ${ }^{56}$.

\section{Bidang Ekonomi}

Berkenaan dengan peran sosial bidang ekonomi, tidak terlepas dari pemikiran K.H. Muhammad Zaini Abdul Ghani pada persoalan kehidupan ekonomi bahwa untuk bisa hidup damai dan sejahtera lahir dan batin harus diberlakukan hukum Islam. Gunanya untuk mendapatkan ketenangan hidup.

K.H. Muhammad Zaini Abdul Ghani juga berusaha menumbuhkan roda ekonomi dengan menanamkan modal kepada orang lain, berdagang barang-barang kebutuhan sehari-hari (sembako). Usaha ini dilaksanakan oleh salah seorang muridnya yang bernama $\mathrm{H}$. Aini yang membuka usaha di Pasar Lima Banjarmasin, hal ini mulai tahun 1978 sampai dengan tahun 1990, dengan perjanjian kesepakatan kalau untung, keuntungannya dibagi dua dan kalau rugi dia sendiri yang menanggung kerugiannya. ${ }^{57}$

Usaha ini dijalankan oleh $\mathrm{H}$. Aini dan selalu mendapat untung. Pada tahun 1980, K.H. Muhammad Zaini Abdul Ghani bisa berangkat haji dengan beberapa orang keluarga berkat hasil keuntungan yang diterima. Tahun 1990, ketika telah berada di Sekumpul pernah juga menjalankan usaha jual beli permata. Modal diserahkan kepada muridnya, yakni H. Suhaidi dan H. Yusuf. ${ }^{58}$ Menurut K.H. Muhammad Irsyad Zein usaha jual beli permata ini, K.H. Muhammad Zaini Abdul Ghani banyak mendapat keuntungan, inilah yang digunakan untuk membangun rumah, membangun musalla Ar-Raudah, kepentingan keluarga dan untuk kepentingan orang lain atau derma. ${ }^{59}$

${ }^{56}$ H.M.Ilyas, (PNS Kantor Wilayah Kementrian Agama Kal-Sel), "Wawancara", Banjarmasin, 12 April 2010, salah seorang murid KH. Muhammad Zaini Abdul Ghani yang selalu mengikuti pengajian dan pembacaan maulid.

${ }^{57}$ H. Ahmad Ridwan, Ulama, "wawancara”, Martapura, 25 Mei 2008

${ }^{58}$ H. Ahmad Ridwan, Ulama, "Wawancara”, Martapura, 25 Mei 2008

Mei 2008.

${ }^{59}$ KH. Muhammad Irsyad Zein, (Abu Daudi), "Wawancara", Martapura, 12 
Usaha jual beli permata ini berlangsung beberapa tahun, bahkan K.H. Muhammad Zaini Abdul Ghani sering memasang cincin di jari dan sering pula murid-murid yang hadir, ketika melihat cincin yang dipakai, mereka tertarik untuk membelinya, dan biasanya Guru Sekumpul tidak menentukan harga. Akan tetapi murid yang membeli inilah yang memperkirakan harga. Berapapun harganya, yang penting mereka merasa senang bahwa cincin yang dipakai, dibeli dari Guru atau Abah Guru. ${ }^{60}$

K.H. Muhammad Zaini Abdul Ghani juga memiliki ruko di Banjarbaru. Ruko ini disewakan, dan dijadikan mini market Berapa jumlah sewa yang diterima, tidak pernah ada yang mengetahui, atau mungkin juga disini ada juga ikut menanam modal. ${ }^{61}$

Usaha lainnya juga adalah jual beli mobil yang dilaksanakan oleh H. Zainuddin Salim (H. Udin Mutia). Usaha berjalan kurang lebih satu setengah tahun. Awal usaha ini hanya beberapa buah mobil, tetapi akhirnya puluhan mobil. ${ }^{62}$

K.H. Muhammad Zaini Abdul Ghani juga memiliki usaha percetakan, namanya "Percetakan Ar-Raudah". Usaha ini dikelola oleh H. Hartani. Disinilah dicetak beberapa jenis kitab, yakni Burdah, Dala'il, Wiridan dan beberapa kitab keagamaan lainnya. ${ }^{63}$

Usaha yang berkembang sampai sekarang dan memerlukan banyak orang yang ikut mengelola di dalamnya yakni perusahaan yang diberi nama "Al-Zahra". Usaha ini pada awalnya K.H. Muhammad Zaini Abdul Ghani mengajak salah seorang muridnya sekaligus pembantunya pada tahun 2003 yang bernama H. Ahmad Ridwan.

\section{Penutup}

K.H. Muhammad Zaini Abdul Ghani memang seorang figur yang memiliki daya tarik dan magnet tersendiri dibanding dengan sejumlah ulama lain se zamannya di Kalimantan Selatan. Ini disebabkan ketokohan dan karisma yang memancar dalam kehidupannya. Peran

${ }^{60}$ H. M. Ilyas, PNS Kantor Wilayah Kementrian Agama Kal-Sel, "Wawancara", 5 Mei 2008.

${ }^{61}$ H. Ahmad Ridwan, Ulama, "Wawancara", Martapura, 25 Mei 2008.

${ }^{62}$ H. Ahmad Ridwan, Ulama, "Wawancara”, Martapura, 25 Mei 2008.

${ }^{63}$ H. Ahmad Ridwan, Ulama, "Wawancara”, Martapura, 25 Mei 2008. 
sosial, kultural, dan keagamaan yang dijalankannya telah mengokohkan dan meneguhkan dirinya sebagai sosok yang karismatik.

Inilah yang dijelaskan oleh Max Weber bahwa seseorang dibedakan dengan orang biasa dan diperlakukan sebagai seorang yang memperoleh anugerah kekuasaan adikodrati, adimanusiawi, atau setidaktidaknya kekuatan atau kualitas yang sangat luar biasa yang tidak terjangkau oleh orang biasa, tetapi berasal dari kayangan. Inilah menurut Weber yang disebut dengan karisma. ${ }^{64}$

Kharisma K.H. Muhammad Zaini Abd. Ghani juga ditopang dengan kemampuannya menguasai ilmu keislaman klasik. Dia mampu menjelaskan dan mengkonstruksi konsep-konsep agama yang rumit dalam bahasa sederhana. Karena itu, ketika menyimak uraian ceramahnya orang mudah mengerti, paham dan tumbuhlah rasa cinta (kagum) kepadanya. Perasaan cinta dan kagum ini pula yang tumbuh di dalam hati ribuan orang muridnya, karena itu, banyak orang yang gemar menceritakan karamah-karamah-nya, meski guru sendiri mengatakan, karamah bukanlah pertanda penting bagi keshalehan seseorang, tetapi konsistensi dalam berbuat kebaikan, jauh lebih baik daripada seribu karamah.

Setelah berpulang ke rahmatullah, makam K.H. Muhammad Zaini Abd. Ghani selalu dikunjungi (diziarahi) oleh masyarakat. Ratusan orang datang setiap hari dari berbagai penjuru tanah air. Hal ini menunjukkan bahwa karisma tidak hilang ketika seseorang meninggal dunia.

Ini sama halnya dengan makam Syekh Muhammad Arsyad alBanjari atau yang dikenal dengan Datuk Kalampayan,atau makam Syekh Yusuf di Makassar atau makan Wali Songo di Jawa yang selalu didatangi

${ }^{64} \mathrm{Max}$ Weber, The Theory of Social and Economic Organization, translated A.M. Henderson and Talcott Parsons, (New York: Oxford University Press, 1947), h.358359. Lihat David L. Sills (ed.), International Encyclopedia of the Social Sciences, (New York: the Macmillan Company \& the Free Press, t. th), vol. 1, h. 386 - 387. Lihat Bryan Wilson, The Noble Savages The Primitive Origins of Charisma and its Contemporery Survival (Berkeley: University of California Press, 1975),h. 4-5, 7-9. Lihat Joachim Wach, Sociology of Religion (Chicago: The University of Chicago Press, 1962), h. 337-341, dan lihat Thomas F. O. Dea, The Sociology of Religion, diterjemahkan oleh Tim Penterjemah Yasogama dengan judul Sosiologi Agama suatu Pengenalan Awal, (Jakarta: Rajawali Press, 1990), h. 44. Lihat Marcia Grad, Charisma, diterjemahkan oleh Anton Adiwijoyo dengan judul "Karisma”" (Jakarta: Binarupa Aksara, 1996), h. 14. 
para peziarah hampir setiap saat. Fenomena ini menunjukkan bahwa karisma tokoh agama yang kharismatik tidak hilang sekalipun telah meninggal dunia. Tesis ini menganulir pendapat Max Weber yang menyatakan bahwa karisma akan sirna seiring dengan wafatnya sang tokoh.

Dengan demikian dapat dikatakan bahwa eksistensi karisma K.H. Muhammad Zaini Abdul Ghani lebih disebabkan karena dia adalah seorang pemimpin umat atau seorang ulama yang mempunyai integritas kepribadian serta kemampuan mengaktualisasikan peran-peran ekonomi, sosial, kultural maupun religiusitas di tengah-tengah masyarakat.

\section{DAFTAR PUSTAKA}

Ahmad Rosyadi, Bertamu Ke Sekumpul, (Cet. III Yokyakarta, PT. LKiS Pelangi Aksara, 2004).

Anang Saifuddin, "Pemakaian Leksikon Bahasa Arab di Kalangan Komunitas Etnis Arab di Martapura", Jurnal Penelitian, IAIN Antasari Banjarmasin, Vol. 9.

Anthony Giddens, Capitalism and Modern Social Theory: an Analysis of Writing of Marx, Durkheim and Max Weber, diterjemahkan oleh Shoeheba Kramadibrata dengan judul; Kapitalisme dan Teori Sosial Modern: Suatu Analisa Terbadap Karya Tulis Marx, Durkheim dan Max Weber, (Jakarta: UI-Press, 1986)

Bryan S.Turner, Weber and Islam, diterjemahkan oleh G.A. Ticoalu, Sosiologi Islam: Suatu Telaah Analisa atas Tesa Sosiologi Weber, (Jakarta: CV. Rajawali, 1984)

Bryan Wilson, The Noble Savages The Primitive Origins of Charisma and its Contemporery Survival (Berkeley: University of California Press, 1975).

David L. Sills, International Encyclopedia of the Social Sciences, (New York: the Macmillan Company \& the Free Press, t. th.), vol. 1.

Departemen P dan K, Kamus Besar Bahasa Indonesia, ( Jakarta: Balai Pustaka , 1995), 
H.A. Athaillah," Perkembangan Tarekat Sammaniyah di Kalimantan Selatan”, Khazanah, Vol. III, No 2, April 2004.

Joachim Wach, Sociology of Religion, (Chicago: The University of Chicago Press, 1962)

Kleden, Etos Kerja Pengrajin Batu Permata Banjar:Pendekatan Antropology (Jakarta: PMB- LIPI, 1996).

M Laily Mansur, Tasawuf Islam Mengenal Aliran dan Ajaran, (Banjarmasin: Universitas Lambung Mangkurat, 1991.

Max Weber, The Theory of Social and Economic Organization, trans. A.M. Henderson and Talcott Parsons (Newyork: The Falcon Wings Press, 1947).

Muhammad Zaini Abdul Ghani, Majmu' Ba'd al-Asanid Ma'a al-Ijarah, (Sekumpul Martapura: Penerbit ar-Raudhah, t.th.).

Mujiburrahman, Mencintai Guru, Banjarmasin Post, 6 Juni 2011.

Musafir Pababbari, Islam dan Politik Lokal Studi Sosiologis atas Tarekat Qadiriyah di Mandar (Makassar: Padat Daya, 2009).

Redaktur, "Belum Ada Tandingannya", Banjarmasin Post, Kamis, 11 Agustus 2005/6 Rajab 1426 H.

Sainul Hemawan, " Jejak Cinta Guru Sekumpul, in Memoriam K.H. Muhammad Zaini Abdul Ghani", Banjarmasin Post, 11 Agustus 2005.

Thomas F. O. Dea, Sosiologi Agama suatu Pengenalan Awal, Tim penerjemah Yasogama (Jakarta: Rajawali Press, 1990),

Tim Al Zahra, al Imdad fi Aurad abl al Widad, (Martapura: Al Zahrra 1426 $\mathrm{H})$.

William Outhwaite, The Blackwell Dictionary of Modern Social Thought, diterjemahkan oleh Tri Wibowo B.S dengan judul "Kamus 
Lengkap Pemikiran Sosial Modern", (Jakarta: Prenada Media Group, 2008)

http://www. Banjarkab. go.id.

http://www.depag.go.id/data- pondok pesantren.

http://www. Banjarkab.go.id 